\title{
Using Cognitive Self-Regulated Strategy Based Program in Developing EFL Student Teachers' Oral communicative competence
}

\section{Doaa Abdelfattah Ahmed \\ Dr. Aly A. Qoura}

Professor of Curriculum \& Instruction (TEFL), Faculty of Education, Mansoura

University

\section{Dr. Adel A. AlSheikh}

Professor of Curriculum and Instruction (TEFL), Faculty of Education, Mansoura University

\section{Abstract:}

This study was conducted to investigate the
effectiveness of using cognitive self- regulated
strategies basedprogram to develop EFL oral communicative competence skills for student teachers. Participants of thestudy were sixty student teachers from Benha university faculty of Education and they were divided into control group and experimental group. Instruments of the study were an oral communicative competenceskills checklist determine the necessary oral communication skills for the student teachers and a pre-post oral communicative competencetest to determine the level of the student teachers' oral communicative competenceskills. After measuring its validity and reliability, the pre-oral communication skills test was administrated on both groups. Results showed no statistically significant differences between the two groups. While teaching the control group with regular ways, the researcher administrated the proposed CSRS-based program on the experimental group.Finally, post-oral communication test was administered on both groups. Results showed that experimental group performed better in the post- oral communicative competence test after the treatment.This showed that the treatment program has an effective impact on improving EFL student teachers' oral communicative competence skills. According to all of that, it could be concluded that using CSRS to develop EFL oral communicative competence skills for EFL student teachers is very effective.

Key words: cognitive self - regulated strategies (CSRS), oral communicative competence, speaking. 


\section{Introduction:}

The main goal of teaching English as a foreign language in most EFL programs is increasing students'proficiency in the foreign language skills: reading, writing, and listening in general and in speaking in particular. The difficulty of learning to speak accurately and fluently is reflected in the number of sub-skills that corporate in the oral production and the few occasions to speak English outside classroom. Most students master the language skills but they cannot communicate fluently or accurately.

Developing oral communicative competence is one of the important goals of English language teaching because it enables learners to communicate successfully in real situations. Speaking involves several elements which make it the most difficult and neglected skill. These elements are pronunciation, communicative $\backslash$ interactive ability and style of speech. Learners need to be successful in specific communicative situations to gain confidence in their ability to speak, monitor and control their own speech. The abilities that learners need to acquire through certain linguistic features can be practiced through intonation; rhythm; reduced speech; linking words; consonants; vowel sounds and word stress.(El-marsafy 2009).

Teaching students how to communicate in English as a foreign language has been generally undervalued and for many years, it has been misinterpreted as involving only drills and memorization of dialogues. Thus, EFL classrooms have many problems such as dominance of teacher-centered teaching approaches, paper-based examinations, students' lack of motivation and interest towards language and lack of opportunity to use the language outside the class. There are also psychological barriers constructed by high effective filters, classroom anxiety and effective factors such as low motivation, shyness, lack of confidence or self-consciousness.

Consequently, researchers have conducted several studies to improve EFL oral communication skills. Using various strategies of cognitive self-regulated is among these strategies 
.Zimmerman (1998) defines self-regulation learning as one's "self-generated thoughts, feelings, and actions for attaining academic goals". Self-regulated learning is a composite process where the learner monitors and controls his/her performance in order to achieve the desired outcome. Paris and Paris (2001) stated that Self-regulated learners are aware of their strengths and their weaknesses, and they control and regulate their own actions towards goals.

According to Zimmerman (2001) and Graham, et al (2005), self-regulation is desirable because of the effects that it has on educational and behavioral outcomes. The use of self-regulation techniques is away to actively engage otherwise passive students in their academic instruction. Students need to view learning as an activity that they do for themselves rather than viewing learning as covert event. That happens to them as result of instruction allowing students to take a more active role in their learning.

\section{Review of Literature:}

This part mentionsthe existing information about the study's variables "CSRS", "oral communicative competence" and "speaking"

\section{Cognitive self- regulation}

There are multiple definitions of self-regulation and selfregulated learning. These are multidimensional constructs which are not easy to describe (Dornyei,(2005). Even the terms and related derivatives investigators employ to label the notion vary (Boeakaerts, Pintrich, \&Zeidner, 2000), ranging from autonomous learning, to self-planned learning or self-education, and self-efficacy (Hiemstra, 2004). Definitions situate selfregulation as an ability or capacity (Lemos, 1999), or as a process (Pintrich, 2000). Other interpretations incorporate selfregulation as strategies (Pintrich, 1999), or "self-generated thoughts, feelings and actions that are planned and cyclically adapted to the attainment of personal goals" (Zimmerman, 2000a, p. 14). 
Zimmerman and Schunk (2001) identified a common conceptualization of self-regulated learning as a psychological construct that describes how learners metacognitively, motivationally, and behaviorally improve their learning and performance. They indicate that self-regulated learners constantly prepare to learn by regulating their own thinking and motivational beliefs as well as managing their resources and the learning environment effectively.

\section{Components of cognitive self-regulation:}

Self-regulation has been described as a triadic reciprocality in which there are three interdependent components: behavioral, environmental and personal (Zimmerman, 1989). The three components, presented below, are not weighted equally, and one or more of the components may function as the main factor at any given time.

\section{Behavioral components of self-regulation}

To be self-regulated, individuals need to use three important processes: self-observation, self-judgments, and selfreaction (Bandura, 1986), which enable individuals to monitor and adjust their behaviours accordingly. These processes are not mutually exclusive, but they interact with each other (Zimmerman, 2001). Self-observation leads to self-evaluation, and the cognitive judgments resulting from self-evaluation lead to personal and behavioral self-reactions (Schunk, 2009).

\section{Environmental components of self-regulation}

Students can acquire information from their learning environment, for example from peer models, and assistance from peers and teachers (Schunk, Pintrich, \&Meece, 2008). Through enactive outcomes and vicarious experience, students attain information regarding self-regulation (Schunk, et al., 2008). In addition to receiving information from the environment, one's control over the environment has been shown to be essential for self-regulation. Seeking social assistance from others and structuring the learning environment are examples of the environmental component of self-regulation. Besides that, the 
classroom social environment can influence self-regulated learning (Schunk, 2009; Zimmerman, 2008).

\section{Personal components of self-regulation:}

Various motivational beliefs underlie each phase of the selfregulatory process (Zimmerman, 2000b). The roles of students' self-efficacy, intrinsic motivation, goal orientation and attribution are discussed in the following paragraphs.

\section{Self-efficacy}

According to Bandura (2001), self-efficacy is seen as a major component of self-regulation, the one's belief about his/her ability to organize actions and shape his/her performance about specific tasks Bandura (1997; 2006) concludes that self-efficacy is an appraisal of the ability to accomplish a certain task. Therefore, self-efficacy is situationspecific. A second language learner may have high self-efficacy for writing essays but low self-efficacy for presenting in public. Social cognitive theorists (Bandura, 1997; Baumeister\&Vohs, 2004; McCombs, 2001; Pajares\&Urdan, 2005) propose that the more the one enjoy self-efficacy, the more he/she can achieve tasks better.

\section{Intrinsic motivation}

Intrinsic motivation is an internal precursor of selfregulated learning. Intrinsic motivation is defined as learners' desire to be involved in tasks for its own sake and without coercion (Schunk, et al., 2008). Vansteenkiste, Simons, Lens, Sheldon, and Deci (2004) reported that learners who were oriented toward an intrinsic motivation showed greater learning and better performance in learning tasks compared to students who were oriented toward an extrinsic motivation.

\section{Goal orientation}

SRL models of regulation assume that learners can set standards or goals to strive for in their learning, monitor their progress toward these goals, and then adapt and regulate their cognition, motivation, and behaviour in order to reach them (Zeidner, Boekaerts, \&Pintrich, 2000; Zimmerman, 2001). Goal 
setting is defined as identifying "the object or aim of an action, for example, to attain a specific standard of proficiency, usually within a specified time limit" (Locke \& Latham, 2002, p. 705). This standard is a basis of personal feedback about one's effectiveness and self-regulatory control (Zimmerman, 2008a).

\section{Attributions}

Another key motivational construct significant for selfregulation is the students' attributions (Schunk, et al., 2008; Schunk\& Zimmerman, 2008). Attributions are student perceptions about the causes of their academic outcomes (Schunk, et al., 2008). People's beliefs about success or failure could be influenced by many variables such as age, cultural influences, gender, and the type of task. In that context, some scholars such as Weiner (1986) adopted the attribution theory of success or failure. He attributed success or failure in tasks to different causes: good or bad luck, difficult or easy tasks, their own hard work or lack of it, or the degree to which they possess certain abilities. Learners should have strong beliefs in their abilities to proceed and accomplish tasks. Thus, motivating students and teaching them how to set realistic goals is highly needed in order not to doubt their abilities if they failed to achieve unrealistic goals (Alderman, 2008).

\section{Cognitive SRL in foreign language learning:}

Recently, self-regulation is highly studied through literature, many researches were conducted to study how SRL's efficacy improve foreign language learning (e.g. Andrade \& Bunker, 2009; Andrade \& Evans, 2013; Gunning \& Oxford, 2014; Ma \& Oxford, 2014; Oxford, 2011; Pintrich\& De Groot, 1990; Sinclair, 2000; Zimmerman \&Risemberg, 1997). Motivating students is highly needed to help students improve their language acquisition. More curricular and extracurricular activities should be conducted to motivate students to be active participants in learning, more self-regulated and autonomous and increase their learning decisions (Oxford, 1990; Pintrich\& De Groot, 1990; Sinclair, 2000). These activities can foster learning and increase performance in language skills such as speaking 
(Ehrman, 1996; Ma \& Oxford, 2014); reading comprehension(Ehrman, 1996); writing (Andrade \& Evans, 2013; Wang, Spencer \& Xing, 2009); and vocabulary (Rasekh\&Ranjbary, 2003).

\section{EFL Communicative competence:}

Communicative competence is used to show how language learners interact with other speakers. It focuses on constructing meaning rather than reciting dialogues or doing discrete point tests of grammatical knowledge. Students can depend on communicative competence if they are encouraged to ask for linguistic and non-linguistic resources. (Brown:2001,Savignon,2007) .

\section{Components of EFL Communicative Competence:}

Aguilar(2002) and baily (2002)presented a framework for communicative competence. The model included six dimensions as follow, although English teachers have been focusing on three components only because they believe that the first three are the only essential.

\section{A- Grammatical Competence:}

According to (Shumin, 1997:8), grammatical competence is a component of communicative competence which focuses on grammar (morphology, syntax), vocabulary, and mechanics. Mechanics are sounds of letters and syllables, pronunciation of words, intonation, and stress. Grammatical competence is effective as it helps speakers to comprehend and utilize English language structures to reach a high level of fluency. (Shumin, 1997: 8).

\section{B- Discourse Competence:}

Discourse competence deals with relationships. Rules of cohesion and coherence are stressed in formal and informal discourse. These rules help in achieving a meaningful way. In discourse competence, one should perceive and process stretches of discourse (Shumin, 1997: 8) to reach positive production and comprehension of the language. 


\section{C- Sociolinguistic Competence:}

If a person acquires language knowledge alone, she/he will not be able to use the target language in a proper way. In addition, learners should enjoy a high social and cultural competence and the appropriate norms of speech acts. Fully comprehending the socio-linguistic side of the language can help learners to know how to ask proper questions and comment appropriately while interaction. Learners also can acquire how to react non-verbally according to the purpose of the speech (Shumin, 1997:8). Thus, sociolinguistic competence was defined as the appropriate use of language in various contexts (Naoko, 2002).

\section{D- Strategic Competence:}

Another component of communicative competence is strategic competence. It refers to the ability to know how to take turns and speak, how to go on speaking, how to end the talk and how to clarify communication and comprehension problems (Shumin, 1997: 8). In addition, strategic competence is seen by Gilfert et al. (1999: 33-49) as social appropriateness and fluency. Also, it is knowing verbal and non-verbal communication strategies (Naoko, 2002).

\section{E-Pragmatic Competence:}

It had a relation with speech acts and language. thornburry(2005:17)explained that the pragmatic competence described the relation between language and its context of use including the purpose for which language is being used.it means how to do things with language, taking in to account its context of use ,knowing how to perform and interpret specific speech acts.

\section{F-Socio -Cultural Competence:}

Every language is situated in asocio -cultural context and implies the use of a particular reference frame which is different partly from that of the foreign language learner. It presupposes a certain degree of familiarity with that context and involves both the will and the skill to interact with other, motivation, attitude, 
self-confidence, empathy and the ability to handle social situation.

\section{Characteristics of EFL Communicative Competence:}

Communicative competence has several characteristics. First, it is dynamic on the negotiation of meaning between people. Second, it applies to all kinds of language systems (e.g. written, spoken, symbolic systems). Third, it needs appropriate choices in an infinite variety of situations. Fourth, it is different from communicative performance because competence is what one knows while performance means what one does. Fifth, it is relative and depends on the cooperative involvement of all the participants. (Qi and Tian ,2010:92).

\section{Oral Communication Skills:}

Oral communication means the appropriate usage of language to serve social interactions. Such various interactions involve both verbal communication and paralinguistic elements of speech such as pitch, stress, and intonation (Shumin, 1997: 8). Also,Hismanoglu (2000) mentioned an example of communication strategies, as circumlocution, gesturing, paraphrase, or asking for repetition and explanation. These techniques are used by learners to help on the continuity of conversation without interrupting the flow of communication.

Chen (2005) declares that "in real-life communication, we use language to express what we mean; however, language is more than a tool for communication, and it is also represents social and cultural background. Learning merely the target linguistic knowledge cannot successfully engage learners into real-life communications in the target culture, they also need to acquire the target pragmatic competence, the capacity to incorporate cultural knowledge into language use and choose appropriate language in different socio-cultural contexts". It can be concluded that speaking is the process of building and sharing meaning through the use of verbal and non-verbal symbols. 


\section{The Communicative Approach in Teaching Speaking}

Interacting is considered a major way for EFL students to learn how to speak. To achieve interacting, communicative language teaching and collaborative learning is highly required, it depends on real-life situations which requires communication. A real-life communication environment which promote oral language should be created by teacher to aid students in their speaking activities, direct them to work in groups and complete tasks. According to Kayi(2006), there is a number of activities that support speaking.

\section{EFL Speaking Skills:}

Developing oral skills of language learners is considered a great challenge for EFL teachers because the main concentration is directed to grammar in teaching courses with a little focus to speaking skills. Speaking is just taught through repetitive drills and memorization of dialogues. According to (Dincer,2011,Tavil,2010,Cole,et al.,2007), the aim of teaching speaking is to develop students' oral communication skills where they can express themselves and communicate effectively.

\section{Nature of EFL Speaking Skills:}

The term speaking has been defined by many researchers (Johnson and Morrow 1981: 70). Speaking is seen as oral communication in which two or more people are involved in an activity to respond to what they are hearing and speak out loud. Both hearers and speakers should agree on the message and language they are using. The elements of the speaking activities are the speakers, the hearers, the message and the response.

\section{Importance of Speaking in EFL learning:}

Due to its interactivity that deals with meaning construction, and information producing, receiving and processing orally, speaking is seen as an important language skill (Florez, 1999). Learning a language should be the sole medium of communication in any given environment. This implies that there is a mutual relationship between communication and speaking. 
What is essential in learning a language is that the language being studied should be, as far as possible, the sole medium of communication in any given environment. He further states that in order to be learnt, a language must be used. This implies that whenever communication takes place, it involves speaking and whenever speaking takes place, it must belong to a certain language.

\section{Challenges of acquiring EFL Speaking Skills:}

Speaking is a difficult skill because effectively oral communication requires the ability to use the language appropriately in social interactions. Diversity in interactions involves not only verbal communication, but also paralinguistic elements of speech such as stress, pitch and intonation. Tsou (2005) indicated that students have problems in speaking because of their negatives attitudes towards participation, low language proficiency, anxiety, learning style, or lack of practice. Shumin (2002) and Yousif and Koveil (1997) indicated that students' problem with oral skills stems from unfamiliarity with using English to communicate their ideas, followed by an inability to express themselves in English.

\section{Related Studies:}

Studies related to developing oral communicative competence

Helwa (2013) investigated the effectiveness of a self autonomy based program on developing EFL student teachers' communicative competence. The design of the study was one group pre-posttest . participants of the study were forty fourth year students enrolled in English section at Benha Faculty of Education $(\mathrm{N}=40)$. Instruments used included an EFL speaking skills checklist; an EFL speaking skills test; EFL writing skills checklist and an EFL writing skills test. Results showed that using self-autonomy based program (SABP) developed writing skills for the participants and their learning autonomy. The researcher recommended that researchers should investigate the 
effect of using other strategies on developing students' EFL communicative competence (speaking and writing skills).

Diyyab (2013) investigated whether multimedia-based program is effective in improving EFL speaking fluency skills for $2^{\text {nd }}$ year English section student teachers or not. Participants were 30 students at Sadat Faculty of Education, Minufiya University, Egypt. The study used an EFL speaking fluency prepost test with a rubric for assessing the participants' performance. After conducting this study, results showed that EFL speaking skills for the participants have been developed due to the training program. Thus, the program was effective in achieving its purpose.

Alnatheer (2013) investigated on how motivation and motivational strategies influence Saudi students' communicative competence. In his study, he made an interview with two groups of 16 participants from Saudi students enrolled in English courses in Australian educational institutions and Saudi students graduated who studied English section in Saudi Arabian high schools. Then, he conducted his research on a large scale as 279 students answered a questionnaire about motivation. Results revealed that participants differ in their competence as The Australian group had higher levels of measured and self-reported communicative competence than the Saudi group. Also, motivation influenced the students' communication competence greatly. Another finding was that the strategies that teachers use in supporting motivation highly increased the students' communicative competence

Dincer, Yesliyurt and Takkac (2012) investigated the effect of autonomy supportive climates on EFL learners' achievement in speaking fluency. Participants of the study were 55 Turkish university students participated in this study as the study sample. Instruments were a questionnaire, a perceived competence scale, an engagement question and demographic questions. results of the study showed that autonomy-supportive instructor behaviours were positively correlated with students' development in EFL speaking fluency skills. 
Studies related to the effectiveness of cognitive selfregulated strategy in teaching and learning EFL

Seker (2015) showed the effectiveness of incorporating self-regulated learning (SRL) strategies into foreign language teaching. The researcher's interviews with teachers $(n=51)$ indicate that they mostly do not consider SRL in classroom practices. The study attempted to highlight the significance of SRL in language teaching by exploring its impact on language achievement. It investigates learner reported use of SRL, focusing on its three main components - orientation, performance, and evaluation, and their power in predicting foreign language achievement. A total of 222 undergraduate foreign language learners at a state university participated in the study. The results showed the importance of SRL research within the foreign language teaching field as well as foster SRL implementation in language instruction.

Mahmoodi, Kalantarib, Ghaslanicthe (2014) investigated the relationship between motivation and SRL, and the relationship between SRL and L2 achievement. 130 EFL learners studying at two language institutes and were selected. A questionnaire including 46 items assessing self-regulated learning and motivation was administered. Running frequency analysis, five most frequently used self-regulatory strategies by EFL learners were specified. In addition, a significant relationship was found between motivation and SRL.

Tasnimi (2014) investigated how can self-regulation affect EFL learners' reading comprehension. Participants of the study were 149 Iranian EFL language learners studying at Islamic Azad Universities of Qazvin and Tehran (North, and Science and Research branches). They were distributed into an experimental group and a control one. The experimental group received direct teaching along with task-based instruction on self-regulation in reading in ten sessions. Results revealed that self-regulation has a significant effect on reading comprehension of Iranian EFL learners. 
Aregu(2013) examined how self-regulated learning development affect the teaching of spoken communication on speaking efficacy and performances among second year students attending spoken and written communication lessons in the College of Business and Economics of Bahir Dar University. 91 students participated in the study. Results showed that experimental group outperformed their control group counterparts in their speaking efficacy. Consequently, it was concluded that much care should be given to improve selfregulated learning in the process of teaching spoken communication.

\section{The Problem of the Study:}

In order to investigate the level of EFL oral communicative competence skills for student teachers, the researcher conducted a pilot study in which the students were requested to answer the oral communicative competence test. Results of the pilot study showed that those student teachers suffer from a lack in their oral communicative competence skills which were required for those student teachers. Therefore, there was a need to investigate this problem.

\section{Problem Statement:}

Despite the great importance of communicative competence for EFL student teachers, there is a noticeable lack of it among them, so there is a need for a study to try to remedy low level of student teachers in the communicative competence. Therefore, the researcher finds it is important to set up a program based on cognitive self-regulated strategies to enhance oral communicative competence for EFL student teachers.

\section{Research Questions:}

The problem of the study was explored through answering the following questions:

1. What are the EFL oral communicative competence components that should be mastered by EFL student teachers? 
2. How far are these communicative competence components mastered by the EFL students?

3. What are the features of a cognitive self-regulated based program to develop oral communicative competence for EFL student teachers?

4. What is the effectiveness of a cognitive self-regulated based program in developing EFL students' communicative competence?

\section{Hypotheses of the Study:}

The study verified the following hypotheses:

1. There is a statistically significant difference at 0.05 level in the mean score of the EFL communicative competence skills on the pre-posttest between the experimental group and the control group in favor of the experimental one.

2. There is a statistically significant difference at 0.05 level in the mean score of the experimental group in the EFL oral communicative competence skills on the pre-posttest in favor of the post test.

There are four sub hypotheses related to the second main hypothesis:

a. There is a statistically significant difference at 0.05 level in the mean score of the experimental group in the EFL grammatical competence on the pre-posttest in favor of the post test.

b. There is a statistically significant difference at 0.05 level in the mean score of the experimental group in the EFL discourse competence on the pre-posttest in favor of the post test.

c. There is a statistically significant difference at 0.05 level in the mean score of the experimental group in the EFL sociolinguistic competence on the pre-posttest in favor of the post test.

d. There is a statistically significant difference at 0.05 level in the mean score of the experimental group in the strategic competence on the pre-posttest in favor of the post test. 
3. There is no statistically significant difference at 0.05 level between the mean score of the control group in pre-and post-administration of the oral communicative competence test.

\section{Purposes}

The study aimed at:

1. Determining the current level of oral communicative competence skills of EFLstudent teachers targeted by the study.

2. Identifying the features of the proposed CSRS training program for improving the EFL student teachers' oral communicative competence skills.

3. Measuring the effectiveness of the proposed training program using CSRS in enhancing the EFL student teachers' oral communicative competence.

\section{Delimitations}

This study was delimited to:

1. A sample of student teachers at Benha University, faculty of Education, English department.

2. Some cognitive self- regulated strategies (goal setting, self-monitoring, self- instruction, self -evaluation, selfcontrol, self -reinforcement).

3. Four oral communicative competence skills required for the target sample (grammatical competence, discourse competence, sociolinguistic competence and strategic competence).

\section{Research design:}

The researcher used the quasi experimental design using two groups: the experimental group and the control group. The experimental group was taught through a cognitive self regulated based program while the control group was taught through the regular way in the class. Both groups received the pre-and post - administration of the oral communication skills test. 


\section{Participants and Setting of the Study:}

\section{Participants}

The participants of the study were 60 student teachers from Benha, faculty of Education, third year English department. Thirty student teachers represented control group and received the regular teaching. Theother thirty student teachers comprised the experimental group and received CSRS training.

\section{Instruments:}

Two instruments will be designed to measure EFL student teachers' communicative competence before and after conducting the program:

a. An EFL oral communicative competence skills checklist to determine the skills necessary for the study sample.

b. A pre-post oral communicative competence test to measure student teachers' oral communicative competence skills before and after the training program.

\section{Results and discussions:}

For the purpose of testing the study hypotheses, the researcher used the difference between students' scores before and after applying the test. Also, different statistical methods were employed through using the SPSS for handling the results, T-test value to show the results of the collected data. Results are shown in the following tables:

Results in table one indicate that the mean score of the students in each oral Communicative competence sub-skill in the experimental post-test was higher than that in the control group post-test administration. The table also shows that the students mean score in the overall post-oral communicative competence test in the experimental group was (48.10) and the control group overall score in the post-test was (31.46). These results indicate that the experimental outperformed the control group in the oral communicative competence post- test. 
JRCIET

Vol. 3 , No. 3

July 2017

Table (1):T-test for the post test score of the experimental and the control group in the oral communicative competence sub-skills and the total score.

\begin{tabular}{|c|c|c|c|c|c|c|}
\hline \multirow[b]{2}{*}{ Skill } & \multirow[b]{2}{*}{ Groups } & \multirow[b]{2}{*}{ Test } & \multirow[b]{2}{*}{ Mean } & \multirow[b]{2}{*}{ SD } & \multicolumn{2}{|c|}{ Paired T- test } \\
\hline & & & & & $T$ & $\begin{array}{c}P \text { - } \\
\text { value }\end{array}$ \\
\hline \multirow{4}{*}{$\begin{array}{l}\text { Grammatical } \\
\text { competence }\end{array}$} & \multirow{2}{*}{ Experimental } & Pre & 7.93 & 3.08 & \multirow{2}{*}{.091} & \multirow{2}{*}{0.001} \\
\hline & & Post & 12.40 & 1.57 & & \\
\hline & \multirow{2}{*}{ Control } & Pre & 7.87 & 2.54 & \multirow{2}{*}{7.807} & \multirow{2}{*}{.928} \\
\hline & & Post & 8.10 & 2.57 & & \\
\hline \multirow{4}{*}{$\begin{array}{c}\text { Discourse } \\
\text { competence }\end{array}$} & \multirow{2}{*}{ Experimental } & Pre & 8.73 & 2.99 & \multirow{2}{*}{.369} & \multirow{2}{*}{0.001} \\
\hline & & Post & 11.97 & 2.24 & & \\
\hline & \multirow{2}{*}{ Control } & Pre & 9.03 & 3.29 & \multirow{2}{*}{6.28} & \multirow{2}{*}{.713} \\
\hline & & Post & 7.87 & 2.79 & & \\
\hline \multirow{4}{*}{$\begin{array}{c}\text { Sociolinguistic } \\
\text { competence }\end{array}$} & \multirow{2}{*}{ Experimental } & Pre & 7.67 & 2.54 & \multirow{2}{*}{.051} & \multirow{2}{*}{0.001} \\
\hline & & Post & 11.77 & 1.96 & & \\
\hline & \multirow{2}{*}{ Control } & Pre & 7.63 & 2.48 & \multirow{2}{*}{7.171} & \multirow{2}{*}{.959} \\
\hline & & Post & 7.80 & 2.31 & & \\
\hline \multirow{4}{*}{$\begin{array}{l}\text { Strategic } \\
\text { competence }\end{array}$} & \multirow{2}{*}{ Experimental } & Pre & 5.47 & 2.22 & \multirow{2}{*}{.369} & \multirow{2}{*}{0.001} \\
\hline & & Post & 11.97 & 2.05 & & \\
\hline & \multirow{2}{*}{ Control } & Pre & 5.67 & 1.97 & \multirow{2}{*}{7.477} & \multirow{2}{*}{.714} \\
\hline & & Post & 7.70 & 2.35 & & \\
\hline \multirow{4}{*}{ Total } & Experimental & pre & 29.80 & 6.06 & 50 & 0001 \\
\hline & & post & 48.10 & 6.39 & .250 & 0.001 \\
\hline & Control & pre & 30.20 & 6.32 & & 007 \\
\hline & & post & 31.46 & 7.03 & 2.592 & 0.000 \\
\hline
\end{tabular}

The paired T-test results indicate that the differences between the mean scores of the student teachers in the post-oral test in the control and experimental group were statistically significant at 0.001 level in favor of the post administration of the oral communicative competence test. These results were due to the implementation of the CSRS training for the experimental group. 
Value of $\left({ }^{\mathrm{D}} 2\right)$ on oral communicative competence skills of the experimental group and control one is shown in table two:

\begin{tabular}{|l|c|c|}
\hline The dependent variable & Value of Eta -square & Level of effect size \\
\hline Grammatical competence & 0.51 & \\
\hline Discourse competence & 0.40 & \\
\hline $\begin{array}{l}\text { Sociolinguistic } \\
\text { competence }\end{array}$ & 0.47 & \multirow{2}{*}{ high } \\
\hline Strategic competence & 0.49 & \\
\hline Total score & 0.61 & \\
\hline
\end{tabular}

Results in table (2) show that the effect size of the CSRS on oral communicative competence skills of the experimental group students in comparison with those of the control group is high. All values exceeded 0.15 which refer to a large effect size for all oral communicative competence skills in the experimental treatment. This result can be explained as follows:

- The eta square value is (0.51) for the first skill (grammatical competence). This means that $51 \%$ of the total variance of the first skill could be attributed to CSRS. This high variance refers to employing a high effect size of the experimental treatment on the first skill since Abo Hatab\&Sadek(1980) indicated that if the effect is $15 \%$ or more it is considered high.

- The eta square value for the second skill (discourse competence) is 0.40 and this refers to $40 \%$ of the total variance of this second skill. This could be attributed to the proposed training (CSRS).

- The eta square value for the third skill (socio linguistic competence ) is 0.47 and this indicates $47 \%$ of the total variance of this skill. This, in turn, signifies a high effect size of the experimental treatment on the third sub-skills.

- The eta square value for the fourth skill (strategic competence) is 0.49 with a percentage of $49 \%$ of the total variance of this skill. This percentage points to a high effect size on this skill due to the experimental treatment.

Regarding the third hypothesis, table (3) shows a comparison betweent-test of the experimental group on the prepost administration of the oral communicative competence test: 
Table (3) :T-test of the experimental group on the pre-post administration of the oral communicative competence test:

\begin{tabular}{|c|c|c|c|c|c|c|}
\hline \multirow[b]{2}{*}{ Skill } & \multirow[b]{2}{*}{ Groups } & \multirow[b]{2}{*}{ No } & \multirow[b]{2}{*}{ Mean } & \multirow[b]{2}{*}{ SD } & \multicolumn{2}{|c|}{ Paired T-test } \\
\hline & & & & & $\mathbf{T}$ & $\begin{array}{l}\text { P - } \\
\text { value }\end{array}$ \\
\hline \multirow{2}{*}{$\begin{array}{l}\text { Grammatical } \\
\text { competence }\end{array}$} & pre & 30 & 7.93 & 3.08 & \multirow{2}{*}{8.28} & \multirow{2}{*}{.001} \\
\hline & post & 30 & 12.40 & 1.57 & & \\
\hline \multirow{2}{*}{$\begin{array}{l}\text { Discourse } \\
\text { competence }\end{array}$} & pre & 30 & 8.73 & 2.99 & \multirow[b]{2}{*}{6.16} & \multirow[b]{2}{*}{.001} \\
\hline & Post & 30 & 11.97 & 2.24 & & \\
\hline \multirow[t]{2}{*}{$\begin{array}{c}\text { Sociolinguistic } \\
\text { competence }\end{array}$} & Pre & 30 & 7.67 & 2.54 & \multirow{2}{*}{8.99} & \multirow{2}{*}{.001} \\
\hline & Post & 30 & 11.77 & 1.96 & & \\
\hline \multirow{2}{*}{$\begin{array}{c}\text { Strategic } \\
\text { competence }\end{array}$} & Pre & 30 & 5.47 & 2.22 & \multirow{2}{*}{17.53} & \multirow{2}{*}{.001} \\
\hline & Post & 30 & 11.97 & 2.05 & & \\
\hline \multirow{2}{*}{ Total } & Pre & 30 & 29.80 & 6.06 & \multirow{2}{*}{16.87} & \multirow{2}{*}{.001} \\
\hline & Post & 30 & 48.10 & 6.39 & & \\
\hline
\end{tabular}

Results in Table threeshow that the students mean score of each oral communicative competence sub-skill in the post-test were increased $(12.40,11.97,11.77$ and 11.97). These results indicate that the higher mean score is for the post administration of the experimental group's post-test. Therefore, the CSRS training was effective in improving each oral communicative subskill. All T-test results were significant at 0.001 level which reflects the significant differences between the mean scores of the experimental group pre-and post-test favoring the postapplication.

A closer look to the total score, table six reports that the students' mean score in the overall pre-oral communicative competence test in the experimental group was (29.80). On the other hand, the experimental group's overall mean score in the post-oral communicative competence test was (48.10). The increase in the mean score of the experimental group in the posttest implies that the students' level in overall oral test have been developed due to the training. 
The paired T-test results indicate that the differences between the mean score of the experimental group students in the pre-and post- oral communicative competence test was statistically significant at $<0.001^{*}$ level in favor of the post application which, in turn, indicates the effectiveness of the CSRbased strategies training in the oral communicative competence skills of the students.

This development can be due to the influence of the self regulated based program on training students how to develop self confidence in their abilities to speak, enhance their communicative and authentic competence between the teachers and them, speak and express what they feel, encouraging motivating atmosphere based on mutual interaction and communication between the teachers and others. So, this development led to accept the second hypothesis.

Table (4):Effect size of CSRS on oral communicative competence skillsof the experimental group:

\begin{tabular}{|c|c|c|}
\hline Dependent variables & Value of Eta square & Level of effect size \\
\hline $\begin{array}{l}\text { Grammatical } \\
\text { competence }\end{array}$ & 0.70 & High \\
\hline Discourse competence & 0.57 & High \\
\hline $\begin{array}{l}\text { Socio linguistic } \\
\text { competence }\end{array}$ & 0.74 & High \\
\hline Strategic competence & 0.91 & High \\
\hline total score & 0.91 & High \\
\hline
\end{tabular}

Table (4) reports the effect size of the proposed training (CSRS) on the oral communicative competence skills of the experimental group students where the highest eta square value is $(0.91)$ for the strategic competence and the lowest value is (0.57) for discourse competence. This resorts to the extra practice and communication during the implementation of CSRS such as modeling, group discussion, using role play and interviews. Guiding them to concentrate on the goals they set before. Encouraging students to reward themselves and keep their rewards in their dairies. 
Regarding the total value of the eta square for all the four skills, it is clear that $91 \%$ of the total variance in overall oral communicative competence skills can be ascribed to the implementation of CSRS. The effect size of the treatment exceeds the minimum percentage level. This indicates a high level of effect size of the experimental training upon the overall oral communicative competence skills.

Regarding the third hypothesis, table (5) shows a comparison between the control group on the pre-post administration of the oral communicative competence test:

\begin{tabular}{|c|c|c|c|c|c|c|}
\hline \multirow[t]{2}{*}{ Skill } & \multirow[t]{2}{*}{ Groups } & \multirow[t]{2}{*}{ No } & \multirow[t]{2}{*}{ Mean } & \multirow[t]{2}{*}{ SD } & \multicolumn{2}{|c|}{ Paired T-test } \\
\hline & & & & & $\mathbf{T}$ & $\mathbf{P}$-value \\
\hline \multirow{2}{*}{$\begin{array}{l}\text { Grammatical } \\
\text { competence }\end{array}$} & pre & 30 & 7.87 & 2.54 & \multirow{2}{*}{1.76} & \multirow{2}{*}{.090} \\
\hline & post & 30 & 8.10 & 2.58 & & \\
\hline \multirow[b]{2}{*}{$\begin{array}{l}\text { Discourse } \\
\text { competence }\end{array}$} & pre & 30 & 9.03 & 3.29 & \multirow[b]{2}{*}{6.06} & \multirow[b]{2}{*}{.000} \\
\hline & Post & 30 & 7.87 & 2.79 & & \\
\hline \multirow{2}{*}{$\begin{array}{l}\text { Sociolinguistic } \\
\text { competence }\end{array}$} & Pre & 30 & 7.63 & 2.48 & \multirow{2}{*}{0.926} & \multirow{2}{*}{.362} \\
\hline & Post & 30 & 7.80 & 2.31 & & \\
\hline \multirow[b]{2}{*}{$\begin{array}{c}\text { Strategic } \\
\text { competence }\end{array}$} & Pre & 30 & 5.67 & 1.97 & \multirow{2}{*}{9.87} & \multirow{2}{*}{.000} \\
\hline & Post & 30 & 7.70 & 2.35 & & \\
\hline \multirow{2}{*}{ Total } & Pre & 30 & 30.20 & 6.33 & \multirow{2}{*}{3.82} & \multirow{2}{*}{.001} \\
\hline & Post & 30 & 31.47 & 7.03 & & \\
\hline
\end{tabular}

The results could imply that the traditional teaching and learning methods of teaching oral communicative competence do not lead to differences in students' oral communicative competence. However, there seems to be some changes, which seem to have resulted from the lessons. From this, one can see that the traditional methods do not have considerable influence on students' oral communicative competence. Overall, the results reveal that the experimental group surpasses the control group 
in oral communicative competence. The results imply that attention needs to be paid to the enhancement of self-regulated learning in the process of teaching oral communicative competence.

\section{conclusion}

The proposed CSRS training of the present study resulted in improving oral communicative competence and the results showed that CSRS are more effective than regular methods for developing oral communicative competence.

These results could be attributed to:

- Students were encouraged to use the language continuously and naturally without hesitation, pauses and speak with acceptable accent.

- Students were able to use the grammatical rules correctly. Use suitable tenses to convey the meaning. Express ideas in complete and clear sentences.

- Use the language appropriately for the proper social setting, audience and the situation. Use appropriate gestures and body language when needed. Perform communicative functions (apologizing, inviting, accepting....), know when you introduce a topic or change the subject.

- Have the opportunity to choose the topics they want to speak about.

- Concentrate on the goals they set before and how they achieve them.

- Students reward themselves by thinking praises such as (I'm getting better at this.), reward themselves and keep their rewards in their dairies.

- Students were interested and involved in the activities and their motivation increased as they work in pairs or groups. 
- Adjust their effort and strategies to the task and to their goals, they know when to persist, when to ask for help, where and how to perform tasks successfully.

On the other hand, it was noticed that at the beginning of the experiment, some students were shy to talk or ask for help and this made them inactive. But when they made interviews, work in pairs, and group work discussion, the problem disappeared. Another problem was that students talked in isolated words or sentences and they can't connect ideas. When students were given more exercises on how to connect sentences and ideas such as storytelling, they got involved and improved their ability.

Regarding the control group, the researcher noticed that the students in the control group didn't show acceptable levels of motivation. They only cared about the exams' score. Moreover, the researcher noticed that students were just following the teacher during the lesson with little interaction. The teacher gave them the main idea to talk about and they just followed their teacher's instructions without adding or thinking about any creative ideas. There was little communication among students themselves.

\section{Recommendations}

Based on the previous results, the present study recommends the following:

1. Oral communicative competence skills should receive appropriate attention in order to be developed especially at secondary school and university years.

2. Cognitive self-regulated strategies should be integrated in the curriculum for student teacher and in the classroom teaching.

3. Not only oral communicative competence skills should be tackled, but also evaluating it regularly in order to identify students' needs and problems. 


\section{Suggestions for further research}

- Investigating the effect of the self-regulated based program on English language learning among secondary and preparatory school students and on other language skills such as listening, writing and reading among college students.

- Investigating the effect of using other strategies on developing students'oral communicative competence skills.

\section{References}

Aguilar,M.J.C.(2002).International Communicative competence: A step beyond communicative competence.ELIA,3,85-102.

Alderman, M. K. (2008). Motivation for achievement: Possibilities for teaching and learning (3 ed.). New York: Routledge.

Alnatheer, A. A. (2013). The role of motivation and motivational strategies in Saudi students' communicative competence in English (Doctoral dissertation, Queensland University of Technology).

Andrade, M. S., \& Bunker, E. L. (2009). A model for self-regulated distance language learning. Distance Education, 30; 47-61.

Andrade, M. S., \& Evans, N. W. (2013). Principles and practices for response in second language writing: Developing selfregulated learners. New York: Taylor and Francis.

Aregu, B. B. (2013). Enhancing self-regulated learning in teaching spoken communication: Does it affect speaking efficacy and performance. Electronic Journal of Foreign Language Teaching, 10(1), 96-109.

Bandura, A. (1986). Social foundations of thought and action: A social cognitive theory. Englewood Cliffs, NJ: Prentice-Hall. Bandura, A. (1997). Self-efficacy: The exercise of control. New York: Freeman

Bandura, A. (2001). Social cognitive theory: An agentic perspective. Annual Review of Psychology, 52, 1-26. doi: 10.1146/annurev.psych.52.1.1 
Bandura, A. (2006). Guide for constructing self-efficacy scales. In F. Pajares\& T. Urdan (Eds.), Self-efficacy beliefs of adolescents (pp. 307-337). Greenwich, CT: Information Age. Bailey, K.M. (2002).Issues in Teaching Speaking Skills to Adult ESOL learners. Available on line at http://www.nova. edu) sss\.

Brown, J. D. (2003). Promoting fluency in EFL classrooms. Paper presented at the JALT National Conference. Nagoya, Japan. University of Hawai'i at Manoa, Proceedings of the 2nd Annual JALT Pan-SIG Conference

Baumeister, R. F., \&Vohs, K. D. (Eds.). (2004). Handbook of selfregulation: Research, theory and applications. New York: Guilford Press.

Boeakaerts, M., Pintrich, P. R., \&Zeidner, M. (2000). Handbook of self-regulation. San Diego, CA: Elsevier Academic Press.

Chen,C,S. (2005) . Relationships between non -native English speaking EFL preservice teachers' English Language Learning strategies and beliefs toward teaching methodologies. Unpublished doctoral dissertation, The Pennsylvania State University.

Cole,D.; Ellis,C.; Mason,B.; Meed,J.; Record,D.; Rossetti,A.; Willcocks,W.;(2007).Teaching speaking and listening : toolkit for practitioners .London: Crown.

Corno, L. (2001). Volitional aspects of self-regulated learning. In B. J. ZimmermanD. H. Schunk (Eds.), Self-regulated learning and academic achievement: Theoretical perspectives (pp. 191-225). Hillsdale, NJ: Erlbaum

Dincer,A., (2011) . Turkish EFL Speaking Course Students' Motivational Orientations and their Instructors' Autonomy Support. Unpublished Master thesis, Erzincan university, faculty of Education, English Language Teaching Department ,Turkey.

Diyyab, E. A., Abdel-Haq, E. M., \& Aly, M. A. S. (2013). Using a Multimedia-Based Program for Developing Student Teachers' EFL Speaking Fluency Skills. Online Submission. 
Dörnyei, Z. (2005). The psychology of the language learner: Individual differences in second language acquisition. New Jersey: Lawrence Erlbaum.

Ehrman, M. (1996). An exploration of adult language learner motivation, self-efficacy and anxiety. In: R.L. Oxford (Ed.), Language learning motivation: Pathways to the new century (pp. 81-103). Honolulu, HI: University of Hawaii Press.

El-Marsafy,A A. (2009). multiple-intelligence theory-based program in enhancing EFL, students composition writing skills , In, A, A. El marsafy and E.M. Abdel- Hack (Eds) new trends in teaching reading and writing, (pp.271332).Benha, Egypt: Middle East Center For Educational Services.

Florez, M. A. (1999). "Improving Adult English Language Learners' Speaking Skills". ERIC Digest. (ERIC Document Reproduction Service No. ED: 435204 ).

Gilfert, S. and Croker, R. (1999). Dialog performances: developing effective communication strategies for non-English majors in Japanese Universities. Aichi Gakuen University. The Internet TESL Journal, Volume. 5, No. 3, March, pp 33

Graham, S., \& Harris, K. R. (2005). Writing better: Teaching writing processes and self- regulation to students with learning problems. Baltimore, MD: Brookes.

Gunning, P., \& Oxford, R. L. (2014). Children's learning strategy use and the effects of strategy instruction on success in learning ESL in Canada. System, 43; 82-100.

Helwa, H. (2013). The Effectiveness of a Self- Autonomy Based Program in Developing EFL Student Teachers' Communicative Competence. Unpublished doctoral dissertation, faculty of education, Benha University, Egypt.

Hiemstra, R. (2004). Self-directed learning lexicon. International Journal of Self-Directed Learning, 1(2), 1-6.

Hismanoglu, M. (2000). Language learning strategies in foreign language learning and teaching. Hacettepe University (Ankara, Turkey). The Internet TESL Journal, Volume. 6, No. 8, August. 
Ibrahim, S. A. M. (2000). A study of some linguistic and cognitive factors thataffect the oral fluency of first year students, English section, facultyof education,Assuit University and suggesting some remedialactivities. M. A. Thesis.

Johnson, K., Morrow, K. 1981. Communication in the Classroom. Harlow: Longman.

Lemos, M. S. (1999). Students' goals and self-regulation in the classroom. International Journal of Educational Research, 31, 471-485.

McCombs, B. L. (2001). Self-regulated learning and academic achievement: A phenomenological view. In B. J. Zimmerman \& D. H. Schunk (Eds.), Self -regulated learning and academic achievement. Mahwah, NJ: Lawrence Erlbaum.

Ma, R., \& Oxford, R. L. (2014). A diary study focusing on listening and speaking: The evolving interaction of learning styles and learning strategies in a motivated, advanced ESL learner. System, 43; 101-113.

Mahmoodi,M.H., Kalantarib,B. and Ghaslanic,R.(2014). SelfRegulated Learning (SRL), Motivation and Language Achievement of Iranian EFL Learners, International Conference on Current Trends in ELT, Bu-Ali Sina University, Hamedan, 6517838695, Iran.

Naoko, T. (2002). Implementing oral communication classes in upper secondary schools: a case study. Minnesota State University--Akita, Japan.

Pajares, F., \&Urdan, T. C. (Eds.). (2005). Self-efficacy beliefs of adolescents. Greenwich, Conn: Information Age.

Pange,J.(2014).Self -Regulated Learning Strategies in Groups of learners, University of loannina (Greece) ISSN: 1392-3137.

Paris, S. G., Byrnes, J. P., \& Paris, A. H. (2001). Constructing theories, identities, and actions of self-regulated learners. In B. J. Zimmerman \& D. H. Schunk (Eds.), Self-regulated learning and academic achievement: Theoretical perspectives ( 2 ed., pp. 253-287). Mahwah, NJ: Lawrence Erlbaum.

Pintrich, P. R. (1999). The role of motivation in promoting and sustaining selfregulated learning. International Journal of 
Educational Research, 31(6), 459-470. doi: 10.1016/s08830355(99)00015-4

Pintrich, P. R., Smith, D. A. F., Garcia, T., \&McKeachie, W. J. (1993). Reliability and predictive validity of the Motivated Strategies for Learning Questionnaire (MSLQ). Educational and Psychological Measurement, 53, 801-813.

Qi,S. and Tian,X.(2010).Conversation Analysis as Discourse Approaches to Teaching EFL Speaking. Cross-Cultural Communication,6(4),90-103.

Randi, J. (2004). Teachers as self-regulated learners. Teachers College Record, 106, 1825-1853.

Rheinberg, F., Vollmeyer, R., \&Rollett, W. (2000). Motivation and action in selfregulated learning. In M. Boekaerts, P.R. Pintrich, \& M. Zeidner (Eds.), Handbook of self-regulation (pp. 503-531). San Diego, CA: Academic Press

Savignon,S.J.(2007). Beyond communicative language teaching : What's ahead? Journal of pragmatics $39,207-220$.

Sayed,M.M. (2005).The effect of using a multiple intelligencesbased training program on developing English majors oral communication skills.Faculty of Education.AssuitUniversity. M.A Thesis.

Schunk, D. H. (2001). Self-regulation through goal setting. Retrieved from http://www.schoolbehavior.com/Files/ Schunk.pdf

Schunk, D. H. (2009). Social cognitive theory and self-regulated learning. In B. J. Zimmerman \& D. H. Schunk (Eds.), Selfregulated learning and academic achievement: Theoretical perspectives. New York, NY: Routledge.

Schunk, D. H., Pintrich, P., \&Meece, J. L. (2008). Motivation in education: Theory, research and applications. New Jersey: Pearson Prentice Hall.

Schunk, D. H., \& Zimmerman, B. J. (Eds.). (2008). Motivation and self-regulated learning: Theory, research, and applications. New York: Lawrence Erlbaum.

Seker,M.(2015).The use of Self-Regulation Strategies by Foreign Language Learners and its Role in Language Achievement. language Teaching Journal,1-19. 
Shumin, K. (1997). Factors to consider, developing adult EFL students' speaking abilities, English Teaching Forum, Volume. 35 No 3, July - September.

Tasnimi, M. (2014). Using self-regulation to enhance EFL learners' reading comprehension. Journal of Language Teaching and Research, 5(4), 844-855.

Tavil, Z. M. (2010). Integrating listening and speaking skills to facilitate English language learners' communicative competence. Procedia Social and Behavioral Sciences 9,765-770.

Thornbury , S. \& Slade , D. (2006) Conversation : From Description to Pedagogy . Cambridge .Cambridge University Press.

Tsou, W. (2005).Improving Speaking Skills through instruction in oral classroom participation.Foreign Language Annals, 38(1),46-55.

Vansteenkiste, M., Simons, J., Lens, W., Sheldon, K. M., \& Deci, E. L. (2004). Motivating learning, performance, and persistence: The synergistic effects of intrinsic goal contents and autonomy-supportive contexts. Journal of Personality and Social Psychology, 87, 246-260.

Weiner, B. (1986). Attribution, emotion and action. In R. M. Sorrentino \& E. T. Higgins (Eds.), Handbook of motivation and cognition: Foundations of social behaviour. New York: The Guilford Press.

$\mathrm{Xu}$, J., \&Corno, L. (1998). Case studies of families doing thirdgrade homework. Teachers College Record, 100, 402-436.

Yousif, A. and Koveil, M. (1997). Speaking difficulties at tertiary level .Proceedings of the $4^{\text {th }}$ EFL Skills Conference on New Directions in Speaking $, 9^{\text {th }}, 10^{\text {th }}, \& 11^{\text {th }}$ December CACE ,The American University in Cairo.

Zahidi,A.M. (2012). Self-regulation in English language learning:

Case studies of six Malaysian undergraduates, A PhD thesis, Victoria University of Wellington.

Zimmerman, B. J. (1989). A social cognitive view of self-regulated academic learning. Journal of Educational Psychology, 81(3), 329-339. doi: 10.1037/0003-066x.37.2.122Z 
immerman, B. J. (2000a). Attaining self-regulation: A social cognitive perspective. In M. Boekaerts, P. R. Pintrich\& M. Zeidner (Eds.), Handbook of self-regulation (pp. 13-39). New York: Academic Press.

Zimmerman, B. J. (1998). Developing self-fulfilling cycles of academic regulation: An analysis of exemplary instructional models. In H. Schunk\& B. J. Zimmerman (Eds.), Selfregulated learning: From teaching to self-reflective practice. New York: Guilford Press.

Zimmerman, B. J. (2000a). Attaining self-regulation: A social cognitive perspective. In M. Boekaerts, P. R. Pintrich\& M. Zeidner (Eds.), Handbook of self-regulation (pp. 13-39). New York: Academic Press.

Zimmerman, B. J. (2001). Theories of self-regulated learning and academic achievement: An overview and analysis. In B. J. Zimmerman \& D. H. Schunk (Eds.), Self-regulated learning and academic achievement: Theoretical perspectives. Mahwah, NJ: Lawrence Erlbaum.

Zimmerman, B. J. (2008a). Goal setting: A key proactive source of academic self-regulation. In D. H. Schunk\& B. J. Zimmerman (Eds.), Motivation and self- - 278 - regulated learning: Theory, research, and applications. New York: Lawrence Erlbaum.

Zimmerman, B. J., \&Risemberg, R. (1997). Self-regulatory dimensions of academic learning and motivation. In G. D. Phye (Ed.), Handbook of academic learning: Construction of knowledge (pp. 105-125). New York: Academic Press. 
